\title{
Studies on Different Levels of Nitrogen Application on Growth and Yield of Amaranthus (Amaranthus tricolor L.)
}

\author{
Pallavi Dehariya $^{1}$, D.K. Mishra ${ }^{2}$, Rajkumar Dhakad ${ }^{1}$ and Arun Kumar ${ }^{1}$
}

${ }^{1}$ Dr. B. R. Ambedkar University of Social Sciences, Dr. Ambedkar Nagar, Indore (MP), India

${ }^{2}$ Krishi Vigyan Kendra, Kasturbagram, Indore (MP), India

*Corresponding author

\section{Keywords}

Amaranthus, Nitrogen, Growth and Yield

Article Info

Accepted:

12 March 2019

Available Online:

10 April 2019

\section{A B S T R A C T}

Amaranthus (Amaranthus tricolor L) is one of the most popular leafy vegetable in India commonly known as Chaulai, belongs to the family Amaranthaceae and genus Amaranthus. An experiment was laid out with objectives to find out recommended dose of nitrogen for plant growth and yield of leafy amaranthus at Horticulture Department, Dr. B.R.Ambedkar University of Social Sciences, Mhow (Indore), Madhya Pradesh during kharif 2018. The experiment was laid out in Randomized Block Design (RBD) with three replications $(\mathrm{R})$ and seven treatments level (T) of Nitrogen i.e. 40,60, 80100 and $140 \mathrm{Kg}$ Nitrogen/ ha. The application of different level of Nitrogen fertilizer significantly influenced the plant height, Number of leaves, leaf length, leaf width, stem diameter leaf area and yield. The linear increase in the total green yield of amaranthus was evident with every increase in dose of Nitrogen. Plant height, leaf length, leaf width, leaf area and fresh weight increased with increase in $\mathrm{N}$ application. Highest vegetables yield were obtained at $140 \mathrm{~kg}$ Nitrogen / ha with a mean yield of $187.90 \mathrm{q} / \mathrm{ha}$ which is statistically different to the control and other treatments except T6 (100 kgN/ha.

\section{Introduction}

Amaranthus (Amaranthus tricolor $\mathrm{L}$ ) is one of the most popular leafy vegetable in India commonly known as Chaulai It belongs to the family Amaranthaceae and genus Amaranthus. The genus Amaranthus include around 60 species in which 18 species are found in India. Most of the amaranthus species are originate from Central and South America, while A. tricolor is considered to originate from India or Southern China, A. blitum from Central Europe and A. dubius from Central America (Yadav et al., 2014).

Amaranth responds to a great extent to major essential elements like $\mathrm{N}, \mathrm{P}$ and $\mathrm{K}$ with regards to its growth and yield behaviors (Thompson and Kelly, 1988). Its production can be enhanced by recommendation and adoption of improved agricultural practices. Among them proper fertilizer management practices are important aspect for higher yield. Generally, inorganic fertilizer improve 
the growth and yield of vegetable crops but its excessive use causes health hazards, create problem to the environment including soil, air and water pollution. Improper application of chemical fertilizer also increases the cost of production. While an ample quantity of nitrogen is required for proper growth of leaf and stem of amaranthus (Opena et al., 1988).

Nitrogenous fertilizers are having profound outcome on the marketable yield (Obreza and Vavrina, 1993). It plays an imperative role as a component of protein, nucleic acid and chlorophyll. Excessive use of nitrogen on the other hand is not only effect the cost of cultivation, but it extends the growing period and delay maturity. Taking into consideration of above circumstances, the objectives of the present studies are to find out recommended dose of nitrogen for plant growth and yield.

\section{Materials and Methods}

The experiment entitled "Studies on different levels of Nitrogen application on Growth and Yield of Amaranthus (Amaranthus tricolor L)" were conducted in Polyhouse at Department of Horticulture, Dr. B.R. Ambedkar University of Social Sciences, Mhow (Indore), Madhya Pradesh during kharif 2018. The experiment was laid out in Randomized Block Design (RBD) with three replications $(\mathrm{R})$ and seven treatments level of Nitrogen (T) during 2018.

The experiment assorted well with seven levels of Nitrogen $(\mathrm{N})$ i.e. T1 (Control plot 0 $\mathrm{kg} \mathrm{N} / \mathrm{ha}), \mathrm{T} 2$ (40 kg N/ha), T3 (60 kg N/ha), T4 (80 kg N/ha), T5 (100 kg N/ha), T6 (120 $\mathrm{kg} \mathrm{N} / \mathrm{ha}), \mathrm{T} 7$ (140 kg N/ha). Data on plants growth including Plant height $(\mathrm{Cm})$, Number of leaves, Leaf length, Plant diameter, petiole length, leaf area and yield/ha were recorded. Data were analyzed using ANOVA and $\mathrm{F}$ values and $\mathrm{P}$ values $(\leq 0.05)$ were calculated and considered as significant.

\section{Results and Discussion}

\section{Effects of nitrogen fertilizer on plant height} (cm)

The application of different level of Nitrogen fertilizer significantly influenced the plant height of amaranthus (Table 1). All the levels of nitrogen application showed gradual increasing trend in plant height at final harvest. Highest plant growth $(45.68 \mathrm{~cm})$ was recorded in $\mathrm{T} 7$ which was closely followed by T6 $(41.80 \mathrm{~cm})$ and T5 $(39.22 \mathrm{~cm})$, respectively, while the lowest $(6.80 \mathrm{~cm})$ plant height was recorded from T1 (control plot) i.e. without Nitrogen application. No significant difference was observed with regards to plant height between $\mathrm{T} 6 \& \mathrm{~T} 7$ and T6 \& T5. The analysis of data and results indicated that nitrogen application increases the plant height in amaranthus at all the levels of Nitrogen application. Similar results reported by Khurana et al., (2016) and found that plant height increased with increase in $\mathrm{N}$ application. Sufficient supply of Nitrogen tends to improve growth and yield in Amaranthus. Similar findings were reported by Chakhatrakan (2003) and Olaniyi et al., (2008).

\section{Effects of nitrogen fertilizer on number of leaves / plant}

Analysis of variance for number of leaves/plant due to application of different levels of Nitrogen fertilizer in amaranthus have been presented in Table 1. Different doses of nitrogen showed a statistically significant variation in terms of number of leaves/plants. The highest number of leaves (13.53) was recorded in T7 which was closely followed by T6 (13.33) and T5 (12.93) respectively at 45 DAS (Final harvest).The lowest (9.73) number of leaves was recorded from control plot (T1 without Nitrogen application). No significant difference was 
observed with regards to number of leaves between T6 \& T7 and T6 \& T5 at final harvest. All the level of nitrogen, which was applied in the present experiment showed an increasing trend in number of leaves/plant. Maximum (13.53) number of leaves/plant at final harvest was recorded in $\mathrm{T} 7$ which was statistically similar with T6 (13.333). The minimum (2.667) number of leaves at final harvest was recorded in control plot. The results indicated that nitrogen increase the growth of plant as well as maximum number of leaves/plant. A vigorous growing plant of amaranthus requires adequate supply of nutrients for its normal growth and development (Hewilt and Smith, 1975). In kale plants, application of $\mathrm{N}$ increased the mean fresh weight and therefore, total leaf yields (Chweya, 1984). Leaf production of kale and collards increased with Nitrogen supply (Kanampiu, 1987). Fritz and Habben (1973) reported that fresh weight of lettuce improved with increased Nitrogen application. Khurana et al., (2016) reported that the number of leaves per plant of amaranthus increased as the nitrogen fertilizer rate increased. Similar results were also supported by Chakhatrakan (2008) and Olaniyi et al., (2003).

\section{Effects of nitrogen fertilizer on leaf length (Cm)}

A significant difference was observed with respect to leaf length in relation with different levels of nitrogen application (Table 1). All the levels of nitrogen application in the present trail showed a gradual increase trend in leaf length of Amaranthus at final harvest.The maximum leaf length $(10 \mathrm{~cm})$ was recorded in $\mathrm{T} 7$ which was closely followed by T6 $(9.60 \mathrm{~cm})$ and T5 $(8.25 \mathrm{~cm})$ at Final harvest. The lowest $(5.98 \mathrm{~cm})$ leaf length was recorded from T1 (control plot). The analysis of data and results indicated that nitrogen application increases the growth in leaf length in Amaranthus. Application of 140 $\mathrm{kg}$ Nitrogen/ha gave highest mean values. Follow by 120, 100 and $80 \mathrm{~kg}$ Nitrogen. The least mean values were obtained with application of $0 \mathrm{~kg}$ Nitrogen/ha.

Hewilt and Smith (1975) also indicated that nitrogen application increases the growth in leaf length in Amaranthus at all the level that can result in good leaf yield and quality. Normally leafy vegetables respond well in terms of leaf yields to supply of nutrients that promote vegetative growth. The leaf length of amaranthus increased gradually in different stages of growth, which was found to be important for yield contributing characters of amaranthus. Similar results were obtained by Prakash et al., (2003) and reported leaf length of amaranthus increased gradually which was found to be important yield contributing characters. However adequate supply of Nitrogen tends to enhance growth and development of amaranthus.

\section{Effects of nitrogen fertilizer on leaf width (Cm)}

Analyses of variance in leaf width of red amaranth on each treatment due to application of different levels of Nitrogen fertilizer have been presented in Table 1. Different doses of nitrogen showed a statistically significant variation in terms of leaf width. All the levels of nitrogen application in the present trail showed a gradual increase trend in leaf width. Maximum leaf width was recorded from treatment T7 $(6.207 \mathrm{~cm})$ which was statistically similar with T6 $(6.167 \mathrm{~cm})$. The minimum $(3.173 \mathrm{~cm})$ leaf width was recorded in the plot $\mathrm{T} 1$ (control plot) at final harvest (Table 1). The analysis of data and results indicated that nitrogen application increases the growth in leaf width in amaranthus at all the levels. The result is confirming with the report of Hewitt and Smith (1975) that 
Nitrogen induce leaf production and expansion in plant which is directly correlated with leaf width. A similar trend of results were reported by Khurana et al., (2016) and reported that better stability of leaf width of amaranthus increased under different levels of Nitrogen.

\section{Effects of nitrogen fertilizer on leaf area (cm)}

Leaf area which is an important parameter as it is related to plant growth, yield, photosynthetic capacity etc. Analyses of variance in leaf area of amaranthus on each treatment due to application of different levels of Nitrogen fertilizer have been presented in
Table 1 The application of different level of Nitrogen fertilizer significantly influenced the leaf area of amaranth (Table 1) The maximum leaf area per plant $\left(205.13 \mathrm{~cm}^{2}\right)$ was recorded in T7 which was closely followed by T6 $\left(185.3 \mathrm{~cm}^{2}\right)$ and T5 $\left(169.56 \mathrm{~cm}^{2}\right)$, respectively at Final harvest. The lowest $\left(112.44 \mathrm{~cm}^{2}\right)$ plant height was recorded from T1 (control plot) without Nitrogen application. Nitrogen fertilizer has significant effects on the growth components. Application of $140 \mathrm{~kg}$ Nitrogen/ha gave highest mean values followed by 120,100 and $80 \mathrm{~kg}$ Nitrogen/ha. Motoh et al., (1986) also reported that increases in leaf area and fresh weight, of vegetable amaranths with increased supply of Nitrogen.

Table.1 Plant growth \& Yield parameters as influenced by different levels of Nitrogen (At final harvest)

\begin{tabular}{|c|c|c|c|c|c|c|c|}
\hline Treatment & $\begin{array}{c}\text { Plant height } \\
\text { (cm) }\end{array}$ & $\begin{array}{c}\text { Nos of } \\
\text { leaves/plants }\end{array}$ & $\begin{array}{c}\text { Leaf } \\
\text { length(cm) }\end{array}$ & $\begin{array}{c}\text { Leaf } \\
\text { width(cm) }\end{array}$ & $\begin{array}{c}\text { Leaf } \\
\text { area(cm }\end{array}$ & $\begin{array}{c}\text { Plant } \\
\text { diameter } \\
\text { (cm) }\end{array}$ & $\begin{array}{c}\text { Yield } \\
\mathbf{Q} / \mathbf{h a}\end{array}$ \\
\hline T1 & 27.233 & 9.73 & 5.98 & 3.17 & 112.44 & 2.06 & 100.35 \\
\hline T2 & 28.847 & 11.46 & 6.50 & 3.56 & 126.58 & 2.25 & 130.44 \\
\hline T3 & 31.253 & 11.80 & 7.39 & 4.18 & 136.20 & 2.39 & 150.56 \\
\hline T4 & 34.18 & 12.40 & 7.49 & 4.30 & 154.10 & 2.44 & 160.31 \\
\hline T5 & 39.227 & 12.93 & 8.26 & 4.70 & 169.56 & 2.76 & 170.68 \\
\hline T6 & 41.8 & 13.33 & 9.60 & 6.16 & 185.30 & 3.32 & 180.53 \\
\hline T7 & 45.68 & 13.53 & 10.00 & 6.20 & 205.13 & 3.68 & 180.79 \\
\hline SE (m)+ & 2.625 & 0.497 & 0.566 & 0.44 & 12.54 & 0.22 & 2.31 \\
\hline C.D. (0.05) & 1.260 & 0.766 & 0.428 & 0.450 & 1.260 & 0.175 & 6.509 \\
\hline CV & 1.998 & 3.538 & 3.051 & 5.483 & 1.998 & 3.648 & 11.499 \\
\hline
\end{tabular}

Effects of nitrogen fertilizer on plant stem diameter $(\mathbf{c m})$

The application of different levels of Nitrogen significantly influenced the plant diameter of red amaranth. A significant variation in terms diameter was recorded under different levels of nitrogen (Table 1). The maximum $(3.68 \mathrm{~mm})$ stem diameter at harvest was recorded in $\mathrm{T} 7$ while minimum $(2.067 \mathrm{~mm})$ stem diameter at harvest was recorded in the control plot. The plant diameter growth stage and in all the growing duration was found to have been increasing as Nitrogen fertilizer increased from 0 up to $140 \mathrm{~kg} \mathrm{Nitrogen/ha.} \mathrm{Application} \mathrm{of} 140$ $\mathrm{kg}$ Nitrogen/ha gave highest mean values. Follow by 120,100 and $80 \mathrm{~kg}$ Nitrogen/ha. The least mean values were obtained in $0 \mathrm{~kg}$ Nitrogen/ha. The results indicated that nitrogen increases the vegetative growth of amaranth as well as maximum stem diameter 


\section{Effects of nitrogen fertilizer on yield/ha}

Total weight of plant per hectare was recorded from all the treatments at harvest. Analysis of variance for total weight of plants per hectare due to application of Nitrogen fertilizer has been presented in Table 1 . Highest vegetables yield were obtained at $140 \mathrm{~kg}$ Nitrogen / ha with a mean of $187.90 \mathrm{q} / \mathrm{ha}$ which is statistically different to the control and other treatments (Table 1). The lowest vegetable yield was obtained at control plot i.e. $0 \mathrm{~kg}$ Nitrogen / ha with mean yield of $103.53 \mathrm{q} / \mathrm{ha}$, Similar results reported by Matoh et al., (1986), found that plant height and fresh weight (yield) increased with increase in Nitrogen application. Sufficient supply of Nitrogen tends to improve growth and yield in amaranthus. The linear increase in the total green yield of amaranthus was evident with every increase in dose of Nitrogen. Similar type of observation has been reported by Khurana et al., (2016), they reported that the application of Nitrogen at the level up to 125 $\mathrm{kg} / \mathrm{ha}$ can be recommended to get higher total green yield.

\section{References}

Chweya, J.A.(1984). Yield and quality of kales as affected by nitrogen side dressing, spacing and supplementary irrigation. Acta Hort. 163:295-301.

Chakhtrakan, S. (2003). Influence of nitrogen fertilizers on the vegetable amaranth production. Thammasat lnt. J. Sci. Tech. 8: 4-8.

Fritz, D. and Habben. (1973). Influence of Fertilization on the quality of vegetables particularly for processing, Acta Hort. 29: 349-360

Hewitt, E.J. and LA Smith (1975). Plant Mineral Nutrition. The English University
Press, London, Pp. 176-222.

Kanampiu, F. K. (1987). The effect of nitrogen rates and source on leaf production, nitrate accumulation and thioyanate content in Kale and collard leaves. M.Sc. Thesis, University of Nairobi

Khurana, D. S. (2016) Performance of amaranthus genotypes for growth and yield under different nitrogen levels, Indian $\mathbf{J}$. Hort. 73(1): 137-140.

Matoh, T.D. Ohta and E. Takahashi (1986.) The effect of dosage and application time of nitrogen fertilizer on growth, yield and quality of amaranthus in Japan-Indonesia, Hort. Abst. 1991 Vol. 61.

Obreza, T. A. and Vavrina, C. S. (1993). Production of Chinese cabbage in relation to nitrogen Source, Rate and Leaf nutrient concentration in Soil Science and Plant Analysis. 24: 13-14 [Cited from Hort. Abstr., 1994, 64 (4): 2751].

Olaniyi, J.O., Adelasoye, K.A. and Jegede, C.O. (2008). Influence of nitrogen fertilizer on the growth, yield and quality of grain amaranth varieties. World J. Agric. Sci. 4: 506-13.

Opena, R. T., Kuo, V. and Yoon, J. Y. (1988). Breeding and Seed Production of Chinese cabbage in the Tropics and Subtropics. Tech. Bui., 17, AVRDC. p. 97.

Prakash, K., Shivshankar, T. and Ramanjini Gowda, P.H. (1993). Line 'tester analysis for hybrid vigour in brinjal. Prog. Hort. 25: 123-29.

Thompson, H. C. and Kelly, W. C.(1988). Cole Crops. In: Vegetable Crops McGraw Hill Book Co. New York. pp. 15, 280-281, 370.

Yadav, R., Rana, J.C. and Ranjan, J.K.(2014). Analysis of variability parameters for morphological and agronomic traits in grain amaranth (Amaranthus sp) genotypes, The Bioscan, 9(4): 1661-1665.

\section{How to cite this article:}

Pallavi Dehariya, D.K. Mishra, Rajkumar Dhakad and Arun Kumar. 2019. Studies on Different Levels of Nitrogen Application on Growth and Yield of Amaranthus (Amaranthus tricolor L.). Int.J.Curr.Microbiol.App.Sci. 8(04): 1423-1427. doi: https://doi.org/10.20546/ijcmas.2019.804.165 